\title{
Methods and Thoughts in the Islamic Theology
}

\author{
Muhammad Zaini \\ Universitas Islam Negeri (UIN) Ar-Raniry \\ muhammad.zaini@ar-raniry.ac.id
}

\begin{abstract}
The discourse that has developed so far around Islamic theology includes the emergence of dominant theological currents due to political factors. Yet if it is explored more in-depth, freedom of thought (tafakkur) is one of the main factors. Based on this understanding, two issues need to be discussed in this paper: First, how are the various methods and patterns of thought that develop in the realms of Islamic theology; Second, what issues are the subject of debate in the realms of Islamic theology. The discussion is carried out by descriptive analysis based on relevant sources that are not limited in number. The discussion results show that the thought processes carried out by kalam scholars (mutakallimin) have had a significant influence on the growth and development of Islamic theology. The arguments of the mind that were fertilized by Greek philosophy and other civilizations also played an important role in developing Islamic theology. Besides, the formation of more dominant schools is due to the different methods of thinking in explaining God, His oneness, and His attributes.
\end{abstract}

Keywords: Islamic Theology, Tafakkur, Thinking Methods

Abstrak. Diskursus yang berkembang selama ini seputar teologi Islam di antaranya bahwa munculnya aliran-aliran teologi dominannya disebabkan faktor politik. Padahal jika ditelusuri lebih dalam faktor kebebasan berpikir (tafakkur) merupakan salah satu faktor utamanya. Berdasarkan pemahaman tersebut, ada dua persoalan yang perlu dibahas dalam tulisan ini, yaitu: Pertama, bagaimana ragam metode dan corak pemikiran yang berkembang dalam khazanah teologi Islam; Kedua, persoalan apa saja yang menjadi bahan perdebatan dalam 
khazanah teologi Islam. Pembahasannya dilakukan secara deskriptif analisis dengan berpijak pada sumber-sumber relevan yang tidak dibatasi jumlahnya. Hasil dari pembahasan menunjukkan bahwa proses kegiatan berpikir yang dilakukan oleh para ulama kalam (mutakalliminn) telah memberi pengaruh signifikan dalam pertumbuhan dan perkembangan teologi Islam. Dalil-dalil akal pikiran yang dipersubur oleh filsafat Yunani dan peradaban-peradaban lainnya juga berperan penting dalam mengembangkan teologi Islam. Di samping itu, terbentuknya aliran-aliran lebih dominan disebabkan perbedaan metode berpikir dalam memberikan penjelasan tentang Tuhan, keesaan, dan sifatNya.

Kata Kunci: Teologi Islam, Tafakkur, Metode Berpikir

\section{Introduction}

Tn studying Islamic theology arguments originating from the al-Qur'an, a particular method is needed to capture the messages. For this purpose,

classical scholars use ilm al-kaläm or Islamic theology as a method to study these arguments. On the other hand, there is a philosophy and logic used by some classical scholars as weapons to fend off the attacks of their opponents, namely Atheists, Jews, Christians, and Magi. They always shake the beliefs of Muslims by using the same weapons. Philosophy and logic then became the first basis for studying Islamic theology. In the realm of Islamic theology, Mu'tazilah is a school that includes elements and philosophical methods. Mu'tazilah was much influenced by Greek philosophy, which entered the Islamic world at the end of the Umayyad reign and developed rapidly during the Bani 'Abbasids. Therefore, Mu'tazilah teachings are known to be rational and liberal. At the peak of its development, Mu'tazilah received the support of the Caliph alMa'mun, the 'Abbasid ruler who ruled 813-833 AD and made it the official sect or school of the state (Nurdin and Abbas, 2012, 9).

The increasingly strong influence of Greek philosophy into Islamic religious thought, Mu'tazilah teachings grew. However, one of the theologians who were initially been followers of the Mu'tazilah, namely Abu Hasan al-Asy'ari, surprisingly expressed his departure and conveyed his theological teachings contrary to Mu'tazilah. The name of the theological stream is attributed to his name, namely al-Ash'ariyyah or followers of al-Asy'ary. In contrast to the Mu'tazilah sect, which is rationalistic in style, Abu Hasan al-Ash'ariyah in his theological viewpoint mostly adopts the sunnah of the Prophet Muhammad through hadith texts (Nasution, 1986, 62-65). At the same time, in Persia, a theological school founded by Abū Manșur Muhammad ibn Muhammad ibn 
Maḥmūd al-Māturīdī, known as the Maturidiyyah school. Except in a few cases, Maturidiyah religious understanding is not much different from Ash'ariyyah account (Nasution, 1986, 62-65). Because of this, Maturidiyah is classified as Ahlu as-Sunnah wa al-Jamā'ah along with Ash'ariyyah.

Muslims at that time were divided into several groups (firqah) theology, which put forward religious arguments to defend the stand of their respective groups. From here, the science of Islamic theology continues to develop. It discusses various problems related to divinity, grave sins, faith and infidelity, reason and revelation, human actions, etc. The emergence of multiple streams of theology in Islam is a consequence that must occur as a result of lively thinking activities among 'ulama'. To understand the methods and patterns of thought of the scholars in theological issues, it can be seen, for example, how different views are quite diverse about the concept of divinity (Hanafi, 1979, 11). Based on the guidance of nas (al-Qur'an and hadith), all Muslims believe that the Islamic divinity is monotheism (Q.S. al-Ikhlash/112: 1-4). However, in empirical reality, teachings about the One God gave birth to various views and theological concepts. So, even though God as the object of belief in Muslims is the same, namely Allah, when it is responded to and understood by many individual Muslims, these teachings give birth to various divine concepts. Some think that God has nature, and some think that they don't. Some teachings or views argue that God possess absolute power over human actions, whereas some views argue the opposite. Some of them think that Allah can be seen with their eyes in the hereafter, and some have different opinions.

The emergence of opinions on various theological problems is motivated by the various paradigms and methods of thinking of Islamic theological schools in describing the object of study. For example, the Mu'tazilah group gives freedom to do and think to humans as a manifestation of God's justice (Nasr, 1996, 9-10). This group is also known as a group that relies heavily on reason. So, that if nas are found to be mut worried against reason, then, the intention of nas must be rationalized so that it is following reason. Meanwhile, in Ash'ariyah, Abū Hasan al-Ash'arī took a middle path between the two extremes: namely the Mu'tazili rationalists who put the position of revelation under reasoning, and the externalists who ultimately rejected the role of reasoning. In general, Ash'ariyah makes reasoning subject to revelation and also leaves human free will (Nasr, 1996, 11-12). Meanwhile, Maturidiyah gave more authority or ability to reason to know Allah and know good or bad actions (Zahrah, 1986, 79-93).

This point is understood that the methods of thinking in Islamic theology can be categorized into two types, namely rational and traditional. Thus, studying Islamic theological schools is an attempt to understand the thinking methods and decision-making processes of the mutakallimin (Muslim 
theologians) in solving theological problems (Razak and Anwar, 2000, 31). Departing from the above frameworks of thought, the author is interested in discussing abour the various methods and patterns of thought in the realms of Islamic theology. The question posed is what the forms of methods and ways of thought that have developed in Islamic theology are? The discussion is carried out in a descriptive analysis based on the relative number of sources.

\section{Discourse on the IIm al-Kalam and Islamic Theology}

Before discussing the various methods and patterns of thought in Islamic theology, we first describe some of the problems related to the term "Islamic theology" and its meaning. This issue is among the issues that are often the subject of discourse in the realms of contemporary Islamic theology. The term "theology" used in Islamic scholarship does not originate from the Islamic tradition. The mention of "Islamic theology" in Islamic scholarship is discussed in a popular discipline under the name ilm al-kaläm. The word "theology" is etymologically derived from Greek, namely "theology", which consists of the word "theos," which means "God" and "logos," which means "knowledge" (Runes, ed., 1977, 293). So, etymologically, theology implies the knowledge of God or the science that talks about God. The term theology is the science that discusses God or knowledge of divinity (Arif, 2008, 46-47). However, from several other meanings, it can be concluded that theology has a broader meaning, namely talking about God and humans to God based on revealed information and based on the study and thought of a pure reason.

The term "theology" is not a new treasure in the history of Islamic thought. This can be traced to the early days of Islam when there was an intellectual transformation through the translation of books of Greek philosophy. Greek philosophers monumental works such as "Aristotle's Theology" and "Elementatio Theologia" were well known among Islamic thinkers. This intellectual transformation is quite reasonable given the dialectical interaction and the development of thought in Islamic civilization (Fakhri, 1983, 19-31). Therefore, theological terms as a substitute for the term ilm al-kalām is nothing but a repetitive historical process (Wolfson, 1-2). From a sociolinguistic point of view, theological terms and 'ilm al-kaläm have the same nuance, namely knowledge that talks about God, who God is, where God comes from, where God is, and how His power. However, the theological naming for ilm al-kalām has its problems. The mention of ilm al-kaläm in terms of Islamic theology has even become a polemic. There are at least two things that can be used as reasons why the term theology in the Islamic thought tradition contains polemics:

First, the word "theos" in the teachings of all religions is a call to divine natures that are under God's control, and each religion has different calls, for 
example, "angel" (Islam), "angelos" (Christianity). "Mallak" (in Hebrew), "ahuras" (Zarathusra), "daivas" (Hinduism), "boddhisatvas" (Buddha), and others. The word "logia" in ancient Greek comes from "logos" which means reason, it can also mean doctrine or theory or science (Arif, 2008 46-47). In this sense, the word "theology" in the traditions of the previous religions is related to the science of religion as a whole and less relevant to ilm al-kalām in Islamic religious knowledge.

Second, the term theology in the Christian tradition talks about various issues related to religion, including how to organize society, interpret the Bible, and the mystical aspects of religion whereas in the Islamic tradition, matters related to law and interpretation and mysticism are studied in figh, tafsir and tasawwuf. The knowledge of God is studied in 'ilm al-kaläm. Therefore, Christian theology is different from 'ilm al-kaläm in Islam. However, the term theology in Islamic studies is often translated as ilm al-kaläm, which is one of Islam's traditional disciplines. At least two reasons why Islamic theology is called ilm al-kalām.

First, the naming of Islamic theology as ilm al-kaläm because of the many disputed issues is Kalām Allah (al-Qur'an). Taftāzānī, in his book Dirāsāt fi alFalsafah al-Islämiyyah explains that this knowledge is called ilm al-kaläm because the first issue discussed in its history is about Kalām Allah (al-Qur'an), whether it is makhlüq (created), or qadìm (not completed), whether he is hadith (new) or qadīm (eternal) (Taftāzānī, 1957, 4). Second, Harun Nasution, in his book Theologi Islam, views it from two perspectives: (1). The objective perspective, namely because what is discussed in this science, is the Kalām Allah (al-Qur'an), an issue which has caused stiff opposition among Muslims in the ninth and tenth centuries $\mathrm{AD}$; (2). Subjective perspective, namely because mutakallimin in their history, often used words or kalām in debates to defend their opinion and stand on religious issues (Nasution, 1986, ix). Whatever the reasons for its mention, 'ilm al-kaläm has historically been formulated as the rationalization of the Islamic creed through the search and formulation of rational arguments. In this context, 'ilm al-kaläm was born as an answer to and a challenge to the faith system outside of Islam which uses a philosophical rational method, either directly or indirectly, which is feared to have the goal of overthrowing the rationality of the Islamic creed (Syafi'i, 2012, 3). But are Islamic theology and 'ilm al-kaläm parallel terms and can be used as scientific substance? In this case, it still raises various discussions among the kaläm scholars.

Thus, there are at least two important things related to the similarity of the term of theology and ilm al-kaläm. Firstly, as long as what is meant is the definition of etymology, the likeness of the word 'ilm al-kaläm to theology' can 
be justified. Both of them direct the object of their study to the divine problem, and therefore their use can be mutually substituted. Second, the two terms similarity in the etymological sense does not necessarily indicate the similarity in the terminological and operational meanings. Therefore, some Islamic thinkers still refuse to use the term theology to refer to ilm al-kaläm. The reason for the rejection is due to the difference in the object of study between ilm alkalām and theology in the Christian tradition. In the Christian tradition, theology describes God and explains other aspects of Christian teaching. For this reason, the rejection is based on differences in the scope of the object of study. On the other hand, those who accept the word "theology" as the equivalent of the word ilm al-kaläm, after understanding the sides of the differences between the two, add special requirements. Behind the word, "theology" must be added with the word "Islam." According to Islamic intellectual traditions, this addition serves as a character and limitation of Islamic theology, not Christianity and others.

In the classical Islamic scientific concept, another equivalent that can be articulated with theology is fiqh. The term fiqh at that time did not describe the object of study in the science of fiqh al-Isläm as it is understood today, namely the issue of Islamic law, instead it was the beginning of the discipline of ilm alkalām as the study conducted by Abū Hanīfah (Cook, 2000, 307-334). Abū Hanifah wrote about al-Fiqh al-Akbar, which was not about the science of fiqh (Islamic law), but rather about the creed, which was the object of the discussion 'ilm al-kaläm. It may be that the science of fiqh that discusses legal issues as is currently developing in Abū Hanīfah's thinking is al-fiqh al-ashgar, while al-figh al-akbar is about Islamic creed. This is because 'ilm al-kaläm and fiqh science are both fiqh or systematized understanding. The first discussion is related to the ușuliyyah field (regarding the principle or the main one), while the second is related to furü'iyyah (branches). However, the history and tradition of Islamic scholarship have eliminated the notion of fiqh used Abū Ḥanīfah (Effendi, 1995, $52)$.

Regarding the terminology of Islamic theology, there are many opinions and differences in understanding expressed by experts following the points of view and emphasis on certain aspects. Some experts emphasize the dimensions of the ontology or object of study, and others emphasize the epistemological or methodological aspects. There are also those who emphasize more on the axiological aspects. Among those that emphasize the dimension of ontology is Muhammad 'Abduh gives the definition (d. $1332 \mathrm{H} / 1905$ AD) who said that 'ilm al-kaläm or 'ilm al-tawhid is the science that discusses Allah, the obligatory qualities and those that are maybe established for Him, as well as what is mandatory to deny from Him, also discusses the Apostles to determine what is 
obligatory, permissible, and forbidden to be attributed to them ('Abduh, 1986, 7). Harun Nasution also conveyed a similar definition that ilm al-kaläm or Islamic theology is a science that discusses Allah, His attributes, prophethood, nature, and God's relationship with His creatures (Nasution, 1987, 28). In simple language, it can be said that the object of 'ilm al-kalām or Islamic theology based on the ontology dimension includes" God and other objects of belief in Islamic creed (Wirman, 2013, 10, Madjid, 2008, 202).

As for the notion of 'ilm al-kaläm or Islamic theology which emphasizes more epistemological and methodological aspects and sometimes also axiological aspects, among others are summarized in the formulation presented by 'Aḍud al-Dīn al-Ijī ( $75^{6} \mathrm{H} / 1355 \mathrm{AD}$ ), namely using the argument to refute fraud in matters of faith (Yusuf, 1990,3). Agreeing with the formulation of this definition, a Muslim scholar from Egypt Muștafā 'Abd al-Raziq cited various definitions, among which were conveyed by Muhammad bin 'Alī al-Tahawī that Islamic theology is "a science that provides the ability to establish Islamic beliefs by proposing argumentation and to dispel doubts (al-Raziq, 1959, 261). Furthermore, a definition that emphasizes more on the axiological aspects, among others, was conveyed by Ibn Khaldūn (d. 806 H / 106 AD) that ilm alkaläm or Islamic theology is "science which contains rational arguments to defend faiths, and rejects groups or bid'ah experts who deviate or deviate from the understanding of the salaf and ahl al-sunnah (Khaldun, tt., 326). This definition is almost the same as the formula conveyed by al-Ghazālī, namely "ilm al-kaläm as the knowledge used to defend the ahl al-sunnah creed and protect it from deviant sects by relying on the al-Qur'an and sunnah and using rational reasons (al-Ghazālī, 13०9, 6-7). Al-Taftāzānī stated that 'ilm al-kalām is one of the rationalistic shari'ah sciences which covers the main points of Islamic faith and plays a role in defending it from various other different views and ideologies (al-Taftāzānī, 1957, 3).

From the various formulations above, both those that emphasize ontology, epistemology, and axiology, it is understandable that Islamic theology as one of the Islamic disciplines is built on a fairly strong foundation. From the review of science's philosophy, the ontological aspects or objects that become the study of Islamic theology are God, apostleship, nature, and God's relationship with His creatures. Meanwhile, from the epistemological or methodological aspects, Islamic theology uses religious thinking by placing revelation as the primary source and reason as a secondary source. Therefore, the process departs from the belief in the truth of God's revelation, and reason functions as an explanatory or reinforcing tool (Nasution, 93). The existence of 'ilm al-kalām or Islamic theology in Islamic scholarship is a fact which shows the creative thinking of the scholars to face the realities of society in the early development 
of Islam. The condition at that time required the scholars to think critically. This is because they are faced with the need to rationalize the creed principles due to the influence of Greek thought that began to develop in the Muslim world. For this reason, it is natural that transcendent-speculative issues dominate the issues discussed by Islamic theology.

\section{Epistemology of Islamic Theology}

Islamic theology rests on an epistemological foundation that aims to respond to two philosophical questions that are commonly asked in all scientific disciplines. First, knowledge of what, and second, how to find out (Kartanegara, 200o, 252-253). The two questions have their character. The first question is related to the object of study or the scope of Islamic theology's discussion. The second question relates to the methods or tools used to obtain this knowledge. From the aspect of the object of study, it is clear that Islamic theology discusses God's issue. Thus, all problems that have to do with God become the discussion of Islamic theology, such as issues of God's nature, God's deeds, and God's words. Besides, what is included in the discussion of Islamic theology is metaphysical issues such as life in the afterlife and those related to other Islamic creeds.

From the source aspect, Islamic theology is very dependent on the authority of revelation (al-Qur'an and sunnah) (Watt, 1992, 74). The text of revelation is the first source or the main foothold of Islamic theology (Abdullah, 1999, 121). With high respect for texts existence, especially the al-Qur'an, despite the variety of methodologies to understand them, encouraging the emergence of the expression that states that mutakallimin will always base their perspective on understanding the al-Qur'an (Murata, 2005, 385). The above statement provides an understanding that according to mutakallimin, revelation is a truth that must be accepted mutlaq (acceptance with imāni), and should not be criticized (Abdullah, 200, 2). When taking the evidence from the al-Qur'an, the mutakallimin will accept the truth of the al-Qur'an. They believe that the alQur'an verses are God's revelations. So, they accept them not because their contents coincide with reason but because of their position as God's words (Dunya, 1968, 61). When applying it as an argument, the mutakallimin's acceptance of the al-Qur'an text as a truth is based more on belief and faith and is not bound by argumentative-rational considerations.

The belief of Muslim theologians in the absolute truth of the al-Qur'an and making it the main reference in theological questions does not mean that they negate the role of reason. Intellect is seen as the power to gain knowledge and is also appreciated for its position and revelation (Nasution, 1986,12). Muslim theologians also believe that muthlak reason is necessary within the framework 
of Islamic theology's basic methodology. This view is shared by all schools of Islamic theology, even among the ahl al-sunnah salafiyyah (ahl al-hadīth), namely the school with the least amount of rationality recognizing that reason is one of the most important sources of knowledge (Zahrah, 1996, 227). Regarding the position and function of revelation and reason in Islamic theological thought, al-Ghazālī, in his book al-Iqtiṣād fi al-I'tiqād explains that the two sources have an interdependent relationship (interdependent) and complementary (complementary). In this case, Al-Gazālī gave an example of the relationship between the eye and sunlight in the process of seeing an object (alGazālī, 1972, 3). The eye can only see things if it is healthy, but even healthy eyes cannot see if there is no light hitting the object. This example, al-Ghazāli concluded that it would be very wrong for people to be sufficient in only one source between revelation and reason. To be content with one source only means a blind person.

\section{Islamic Theological Methodology and Framework}

Thinkers have different names to introduce the method of Islamic theology. Some call it the dialectical method (jadali), the method of reasoning (bayāni), and the method of faith (imāni). The dialectical method (jadali) was introduced by Nusabeh (Nusabeh, 1996, 826-840), while al-Jābirī conveyed the method of reasoning (bayāni), and the method of faith ('̄māni) is Hassan Hanafîs view (Hanafi, 2003, 31). The three figures, with the terms, used respectively, try to present certain aspects of the building of Islamic theological methodology. Nevertheless, philosophically each of these terms can meet at a common point, namely the basic idea that the method of Islamic theology, regardless of what title is used, is highly dependent on the authority of the text (religiousrevelation), and still takes advantage of the important sense as a secondary source. All mutakallimin still adhere to the leading source $(a s ̦ l)$ in the form of the al-Qur'anic text, either directly or indirectly, and are based on authentic narrations. The potential reason or ratio as a secondary source is directed to understand and strengthen what is explained in the al-Qur'an text (Muslih, 2004, 204). Theologians make revelation and reason as sources, they cannot mutually deny each other but need each other (functionally complimentary).

The intellectual work patterns used by theologians when dealing with theological questions are as follows: a. Search and, at the same time, find references that come from both the verses of the al-Qur'an and the authentic hadiths; b. When references to both the al-Qur'an and the hadith are found, their existence is immediately believed to be muthlak truth based on faith, and there is no doubt about it; c. Revelation texts that are believed to be true are then understood by using reason or reason. From the three steps above, it can 
be understood that the method of thinking of Muslim theologians first relies on revelation and then uses reason to understand it. They give priority to the text of the al-Qur'an because it is a revelation from God that cannot be doubted the truth, not because it is under reason (Nasution, 91). This method by Hassan Hanafì is called the religious thinking method. This refers to the starting point from the revelation as a primary source, then strengthening by reason as a secondary source. This method of thinking is usually confronted with a philosophical method that promotes free thinking (Hanafi, 32 ). Therefore, it is not wrong to say that it is impossible to become an infidel by studying Islamic theology. The reason is, whatever the flow of Islamic theology, always uses the method of religious thinking.

The method of religious thinking described above is very different from the thinking model applied in Islamic philosophy. The working pattern or methodology of the Muslim philosophers is first to study philosophy and refer to nas or revelation texts. In this case, they put reason or reason ahead of nas or revelation (Hanafï, 32). Therefore, for philosophers, if there is an agreement between the product of thought and the meaning of the al-Qur'an text, there is no problem that becomes a polemic. However, if there is a conflict between the product of thought and the text of the al-Qur'an, then the text must be given a metaphorical meaning (rationalized) so that it is compatible with reason. In the context of Islamic theology, there are two ways to obtain knowledge from revelation according to the framework of bayani reason. a. Using linguistic analysis in studying the editorial of the verses of the al-Qur'an. In this context, the understanding of the al-Qur'an verses is carried out based on the rules of the Arabic language, especially the science of nahwu and saraf; b. Using the analogy method (qiyas), which is known in Islamic theology as istidlāl.

In the case of linguistic analysis, there are differences of opinion among theologians about the lafaz and the meaning of the verses of the al-Qur'an, whether a lafaz is given a sense in accordance with the context or the original meaning. According to the Mu'tazilah group, lafaz or words are given importance based on their context. Meanwhile, according to the textualist ahl al-hadith group, lafaz or words are given meaning based on their original purpose. The difference of opinion between the two groups is motivated by different points of view regarding the lafaz or the al-Qur'an text. According to ahl al-hadith, lafaz or words in the al-Qur'an originally came from God, sent down to His Messenger to be conveyed to his people. Therefore, according to ahl al-hadith, every word in the al-Qur'an must be preserved as the original, because a change in editorial will change the meaning. The opinion of ahl al-hadith is following the basic assumption of Arabic reasoning in which the text gives birth to purpose, not meaning that consumes the text. Likewise, the science of 
nahwu, born from this basic assumption, plays a role in protecting the text from possible deviations of meaning. As for Mu'tazilah, a lafaz is not mutlaq in the sense that it depends on the human condition and the environment as a condition.

Furthermore, in terms of the analogy method, it is similar to the qiy $\bar{a} s$ method in ușülal-figh. However, the mutakallimin prefer to use the term idtidläl, which is more precisely called istidläl bi al-shahìd 'alā al-ghaib. The theologians interpret the word al-shahid as a human being and their characteristics, while the word al-ghaib means God. Therefore, istidläl means understanding God (alghaib) through understanding humans and nature (al-shahid) (Muslih, 210-211.). This method of thinking, according to 'Alī Sāmī al-Nashār, is an original method from Islamic circles (al-Nashār, 1974, 110). Al-Ghazālī in his various works, also very strongly uses this method of thinking (Jahja, 1996, 184). The majority of mutakallimin also prefer to call their method not qiyās, but istidlāl, which is reasoning against unseen knowledge based on external (material) phenomena or commonly referred to as itibār. Some mutakallimin views that this i'tibār method needs to be used as it applies to qiyās. They base on QS. al-Hashr / 59: 13, "So take the incident to become i'tibär"; and also in Q.S. Ali 'Imran/3: 13, "Verily in this there is 'ibrah for those who have eyes or eyes of the heart." The purpose of $i t i b \bar{a} r$ is to return something proportional to it, where it is named așl (origin) to which its comparative is returned likewise. The I'tibār that applies among mutakallimin is a path from the known to the unknown or unknown, namely from the original law or asy-shahìd known to the branch law al-ghaib as something that is not yet known or knowledge of which is sought (al-Jābirī, 143). In Islamic theology, istidlāl is divided into four forms, each of which is a way or model of operation:

a. Istidlāl, which is based on similarity in terms of designation (dalālah). For example, to know that God is All-Willing, God's will is analogous to the empirical condition of man. When it is known that humans have an intention and action, God does too. Another example that Allah is Almighty through His deeds can also be analogous to humans capable of performing activities. The similarity between the concrete-empirical and the abstract is in the way of knowing decision making. Capability is logically ascertained because of the validity of the action. This method underlies knowledge of the attributes of God. b. Istidlāl, which is based on the equality of 'illat. For example, it is impossible for God to do evil because His knowledge of it is drawn on the basis of the same reason or reason that humans also do not do bad things if they know evil deeds. This method is widely used by Mu'tazilah, for example, for knowledge of Allah's justice and for Ash'ariyah to determine Allah's nature in addition to the substance. 
c. Istidla $l$, which is based on the similarity that applies to the place of illat, or based on similarity to something like' 'illat. On the one hand, the state of "will", for example, can be known in a straightforward/axiomatic manner (no need for thought). It means that we have assigned attributes to the subject based on concrete facts with indications of the actions performed. On the other hand, we know the validity of assigning the same thing to the abstract (Allah) to draw conclusions by assigning these attributes or attributes that Allah has the most Will.

d. Istidla $\bar{l}$, which is based on the understanding that unseen realities have a higher ontological status than empirical ones. In other words, this model points to the same conclusion that the concrete world (empiric) is considered more logical to apply to the abstract world (al-ghaib). In fiqh, it is called al-qiyās alawla. An example is this: when we know that we have to behave well because that is good, how much more so is God who knows.

The line of thought model used in theology is deductive (Mudzhar, 2000, 2766, Abdullah, 221-244). This means that the mindset is very much determined by revelation as a major premise, departing from general axioms and ending in specific knowledge. This kind of mindset, by 'Abid al-Jābirī called the mindset bayāniyyūn, not 'irfāniyyūn, nor burhāniyūn (al-Jābirī, 1991, 143). Amin Abdullah said that the deductive line of thought used in Islamic theology was very similar to Plato's model of thinking, the innate ideas in Plato's deductive model were replaced by the verses of the Al-Qur'an and the traditions of the Prophet Muhammad (Abdullah, 221-244). In its application, deductive logic uses thinking tools in the form of syllogisms, the same as those used in Islamic philosophy, namely a method of drawing conclusions or knowledge-based on-premises, major and minor. However, there are differences between the two, especially in terms of the quality of the premise. In philosophy, what is made the major premise must be primary, correct, certain, and convincing after passing a rational test, either through verification or falsification (the dismantling of theories through facts), whereas in Islamic theology, the major premise is taken from something that is accepted. in general (opinions) from society or those derived and believed from religion without going through a rational test (Bakar, 1997, 105-106).

\section{Various Types of Thinking in Islamic Theology}

Another reason that is also seen as the main factor that can trigger differences of opinion in formulating Islamic theology is the difference in principles from the method of thinking. This problem has even become one of the main themes in the study of Islamic theology and has even led to various theological schools' birth (Muzani, ed., 1995, 7). In its history, the beginning of 
the emergence of Islamic theology was always preceded by a building of thought. Then after the flow was able to survive in the arena of thought with its fanatical supporters, a character who systematized the structure of thought was born. At that time, Muslim theologians made controversial theological questions a topic of discussion and dialectic discourse, offering speculative evidence to defend their position. These discussions and dialectical discourses continued and developed during the Umayyad dynasty and achieved progress during the 'Abbasid dynasty.

In the discussion of Islamic theology, Mu'tazilah has a more complex and perfect view in offering speculative evidence formulated during the first period of the 'Abbasid dynasty, to be precise, after contact with Greek thought. Mu'tazilah figures who are quite famous are Abū al-Huzail al-Allaf (135-235 H / $\left.75^{2849} \mathrm{AD}\right)$ and al-Nazzam (185-221 H / 801-835 AD). Meanwhile, the Ash'ariyah founded by Abū Hasan al-Ash'arī (873-935 AD), is seen as a traditional school. As a result of developing the method of thinking in solving theological problems, several school categorizations emerged, as follows (Ansari, 1984, 92).

a. Anthropocentric Flow; anthropocentric theologians consider the essence of transcendent reality to be intracosmic and impersonal. It is closely related to the cosmos, both natural and supernatural elements, and humans are children of the cosmos. The supernatural element in man is the source of his strength. The human task is to let go of the evil natural ingredients. Thus, humans must be able to erase their human personality to gain independence from their natural bonds. People belonging to this group have a negative view of the world because they think their safety lies in their ability to get rid of all their desires and desires. Anthropocentric humans are very dynamic because they consider transcendent, intracosmic, and impersonal realities to come to humans in the form of power since they are born. The power is in the way of potential that makes it able to distinguish between good and evil.

b. Theocentric School; theologians who adhere to the theocentric school believe that the essence of transcendence is supra cosmic, personal, and divine. God is the creator of everything in this universe, and with all His power, God can do anything absolutely. Humans are His creatures, so they must do only for Him. In this relative condition, the human self is an immortal migrant who will soon return to God. For that, man must be able to increase harmony with the ultimate and transcendent reality through piety. With his piety, humans will get the perfection they deserve, according to their nature. With that perfection, too, humans will become ideal figures who can radiate divine attributes in their mirror. This kind of condition will eventually save his fate in the future. Theocentric man is a static individual because he is often trapped in absolute submission. 
c. Convergence or synthesis flow; convergence theologians hold the view that the essence of a transcendent reality is supra and, at the same time, intracosmic, personal, and impersonal. The existence of lähüt and nāsūt, God and being, compassionate and evil, perishing and immortal, and other dichotomous qualities is the reason for this flow of convergence. Ibn 'Arabī refers to these dichotomic traits with the term insijām al-azäli (preestablished harmony). This flow views that the whole cosmos, including humans, is a reflection and disclosure of asma' and mutlaq relativity ('Arabī, tt., 22). This school believes that the essence of human power is a process of cooperation between transcendental (God) forces in the form of wisdom and temporal (human) power in a technical form. As a result, when human power does not participate in the process of events that occur to him, it is the transcendental power that processes an event that happens to him. Therefore, he received no reward or torment from God. On the other hand, when an event occurs in man, while he has tried to do it, there is harmonious cooperation between the transcendental and temporal forces. Consequently, humans will get reward or torment from God, as much as their temporal contribution in actualizing certain events. Thus, the profane freedom of the human will always coexist with determinism.

d. The Nihilist School; nihilist theologians believe that the essence of a transcendental reality is only an illusion. Even this school rejects a muthlak God, and only accepts various variations of the cosmos God. According to this school, humans are only specks of mechanism in a completely coincidental cosmic body. Strength lies in our intelligence to make the best of the worst offer. For this reason, ideally, humans have physical happiness, which is the central point of human struggle ('Arabi, tt., 22). It can be understood that all theological schools in Islam, both Mu'tazilah, Ash'ariyyah, and Maturidiyyah, all have their thinking methods to solve theological problems that develop among Muslims. The difference that appears is only in the portion played by reason in solving these theological problems. Mu'tazilah group argues that reason has very strong power so that it can establish a law. Meanwhile, the Ash'ariyyah group claims that reason has weak power. Also, in terms of holding on to revelation, the differences that arise between Islamic theological schools are only differences in the interpretation of the al-Qur'anic text and hadith, not in their acceptance as a source of Islamic theological teachings. It is the differences in performance that give rise to various currents in Islamic theology.

\section{Application of Tafakkur in the Debate of Islamic Theology}

Truth claims are commonplace in every school of Islamic theology. The goal is good, namely, for the sake of an obsession with monotheism God. Therefore, all schools consider that the theological teachings they develop are the most 
appropriate to affirm God. From the issue of tawhid, the debate between Islamic theological schools has developed into many problems. Each school of Islamic theology has a different understanding of the divine problem and other problems related to it, raising arguments to defend their respective groups. In this paper, only three kinds of contentious issues are discussed, namely:

a. Problems of Intellect and Revelation

Some questions about reason and revelation, namely the extent to which human reason's ability to know God and the obligations that God has imposed on humans? And to what extent is the function of revelation in explaining these two things? The word sense ('aql) is the mașdar form of' aqala, which means to use reason. The word 'aqala in the form of ficil (verb) means habasa, which means binding or captivating (Manzur, 1978, 485). A person who uses his mind is called 'aqil (one who can bind and hold his lust). The meaning of reason, according to Muhammad 'Abduh is a force that only humans have, and therefore, differentiates humans from animals (Faris, 1979, 325). The word "revelation" comes from Arabic, namely al-wahy, which means sound, fire, and speed. Also, the word revelation also means whispers, signs, writings, and books. Furthermore, it also implies notification secretly and quickly. In terms of terms, revelation means hidden notification and is carried out very quickly. However, the word al-wahy is better known as the meaning of what God conveyed to the prophets and apostles.

The problem of the ability of reason and the function of revelation in Islamic theology is related to two main problems, namely: The first is about ma'rifatullāh (knowing Allah). This problem also relates to huṣūl al-ma'rifah (the process of knowing Allah) and wujüb ma'rifat Alläh (obligation to know Allah). The second is about al-husn wa al-qubhu (good and evil). This problem also relates to ma'rifah al-husn wa al-qubhu (how to know good and evil) and wujūb i'tināq al-hasan wa ijtināb al-qabīh (obligation to do good and stay away from bad). Then, which of the four problems in the area of reason, and which is the area of revelation? Various opinions and arguments emerged from multiple schools of Islamic theology. Ash'ariyyah, argues that all obligations imposed on humans can only be known through revelation and not through reason. In this case, reason cannot make something obligatory, nor can it know what is right and what is bad, because goodness is acceptable according to the Shari'ah, not according to reason and bad. Therefore, humans cannot know that they must do good and stay away from bad ('Abduh, 11). Reason can indeed know God, but the obligation to know God must be established by revelation. Likewise, actions that bring rewards and sins can only be known through revelation. Although the Ash'ariyyah gives a high appreciation for the position of reason, in dealing with problems that contradict the opinion of reason and revelation, it prioritizes 
revelation ('Abduh, 11).

Unlike the opinion of the Ash'ariyyah group, for the Mu'tazilah, reason can know everything. Even basis is obliged to know the existence of God even without any information from revelation. One of the important figures of Mu'tazilah Abū al-Huzayl emphasized that before Allah sent revelation, humans had an obligation to know God by reason. Likewise, the opinions of other Mu'tazilah figures, such as al-Nazzam and al-Jubba'i (Nasution, 8o-81). Regarding good and bad, Mu'tazilah also argues that reason has high power given by God to humans. This is a form of God's justice and as a facility given to humans to distinguish between good and bad and do good and stay away from bad. Good and bad are natural (pure) that can be known by reason. Religion, through revelation, is unable to change the essence of good and evil. If religion denounces something bad, it is because badness is something despicable, and if religion encourages goodness, it is because goodness is a laudable thing. Not the other way around; something is not immediately good or bad because religion orders or prohibits it. Therefore, humans are obliged to do good and stay away from bad. In this matter, Mu'tazilah adopted the doctrine of rationalism from one of Yuhanna al-Dimasyqi's disciples named Thabit bin Qurrah, who was so persistent in proving Christian doctrine using pure logic. Based on this doctrine, Mu'tazilah voiced the famous slogan "al-fikr qabla al-sam'i (logic before revelation) (al-Syamali, 1978, 196-197). As for the al-Maturidiyyah group, which was pioneered by Abū Manūur al-Maturidī in its theological thinking, it was heavily influenced by Imam Abū Ḥaniffah lot of ratio in his religious views. In matters of reason and revelation, al-Maturidiyyah argues that reason can know the obligations imposed on humans (Nasution, 76). Allah's commands and prohibitions are closely related to the nature of an act, while the rewards and punishments depend on the nature of the act. Thus, the reason knows that doing good is good and doing evil is bad. This knowledge of reason further strengthens the existence of Allah's commands and prohibitions. Even so, alMaturidiyyah did not explain whether it is obligatory to do good and leave evil before the revelation (Nasution, 76).

b. The Issue of Big Sins, Faith and Kufr

There are many arguments in the al-Qur'an that explain the division between big sins and minor sins. Among them are in the Q.S. al-Nisā'/4: 31, which means: "If you stay away from big sins that are forbidden to you, We will surely forgive your mistakes (small sins), then We will put you in a glorious place (heaven)". Responding to the problem of sin, the scholars of the Ash'ariyyah group agree that the sins that have been committed can be erased by tawbat al-nașüha (sincere repentance). Also, they also agree that people who justify immorality or deny an obligation established by religion are classified as 
kafir. According to the Khawārij group, carrying out religious orders, as stated in the al-Qur'an, such as praying, fasting, being honest, and upholding justice, are part of faith. They argue that faith is not enough just conviction in the heart and speech, but must be proven by deeds. Therefore, Khawārij classified as kafir people who believed in Allah's oneness and the apostleship of the Prophet Muhammad but did not carry out Allah's commands and prohibitions.

One of the most notorious subsects of Khawārij, Azariqah, uses a term heavier than the term kafir by referring to the "idolaters" of people outside their class. As for the perpetrators of grave sins, according to Azariqah, their faith has changed to kafir millah, namely leaving Islam, and the punishment is eternal in hell. Likewise, the Najdah subsection is extreme, calling "musyrik" for perpetrators of minor sins, and calling "kafir" for perpetrators of major sins that are not committed continuously. Thus, the meeting point between the two subsects is that a person who commits a grave sin means losing his faith and therefore becomes an infidel ('Imarah, 2007, 308). However, the Khawārij subsect is classified as moderate, namely 'Ibādiyah, which argues that the perpetrator of grave sins remains as muwähid (one who affirms Allah), but is not a believer. The perpetrator of grave sin is still called an infidel even though he is only a blessed kafir (denying Allah's favor), not an infidel millah. The torments they will receive in the afterlife are eternal in hell with other unbelievers (Rozak and Anwar, 2000, 143). The Murji'ah group is of the view that matters of faith and disbelief are matters of the heart. There is a famous slogan from the Murji'ah group: sin means nothing as long as there is faith, and kufr means nothing as long as there is obedience. In this case, they judge that faith is the belief in Allah and His Messenger, so whoever makes a vow in his heart with the word shahādat, it is sufficient to include him in the ranks of those who believe even though he claims to be an infidel, he is worshiping an idol. And even die in that state.

The Mu'tazilah group's opinions about faith and infidels were strongly influenced by their uṣul al-khamsah (five basic pillars), namely: al-'adl, altawhìd, al-wa'du wa al-wa'è, al-manzilah bayn al-manzilatain, al-amr bi alma'rüf wa al-nahyu 'an al-munkar ('Imarah, 2010, 649,650). Based on the concept of al-ușül al-khamsah, especially al-wa'du wa al-wa'ìd, Mu'tazilah considers that faith is not enough just confession in the heart, but must be proven by deeds. In matters of faith, Mu'tazilah agrees with Khawārij. Regarding the status of the perpetrator of grave sin, Mu'tazilah disagrees with Khawārij's view of being the perpetrator of grave sin and rejects the opinion of Murji'ah, who views the act of grave sin as not affect faith and also rejects the opinion of Hasan al-Basrī who says that the perpetrator of sin big is hypocritical. According to Mu'tazilah, the perpetrators of major sins do not become infidels, nor do they become 
hypocrites, but those who commit grave sins are wicked. The perpetrator of grave sin is between the unbelievers and the believers, and he is eternal in hell, but his torment is lower than the suffering of unbelievers ('Imarah, 2010, $649,650)$.

Furthermore, Abū Hasan al-Ash'arī's views on the issue of faith and kafir are relatively difficult to understand. Because in his works such as the books of Maqālāt, al-Ibānah, and al-Luma', al-Ash'arī's explanation of faith varies. In the Maqālāt and al-Ibānah books, al-Ash'arī states that faith is qaulun and 'amalun (words and deeds), and can increase and decrease. Meanwhile, in his book alLuma', he defines faith as tașdī bi Allāh (confirming the existence of Allah). AlShahrastani explained the definition of faith meant by al-Ash'ari by quoting alAsh'ary's words as follows: “... faith is essentially tașdì bi al-qalb (justification by heart), while making a verbal pledge, and carrying out by deeds (iqrār bi al-lisān wa 'amāl bi al-arkān) are only furu' (branches) of faith. Therefore, anyone who acknowledges oneness and power and believes in the Prophet and Rasul as messengers of Allah, this kind of faith is true faith (sahih), and a person's faith will not be lost unless he denies one of these two things". Al-Shahrastanī's explanation, besides combining the two different definitions in Maqālāt, alIbānah and al-Luma' to one point, also places the three elements of faith (tașdīq, $q a w l$, and 'amal) in their respective positions. Thus, for al-Ash'ari and the Ash'ariyyah group, the minimum requirement to be called a believer is tasdīq (justification in the heart), which, if displayed in real terms, takes the form of pronouncing syahādatain (Razak and Anwar, 148, 149).

Therefore, ma'rifah and 'amal are not part of faith. Humans can know ma'rifah and 'amal this only based on revelation. In other words, it is a revelation that explains to humans the obligation to know God, and humans must accept the truth of this news. The loss of something which is not a condition for the existence of a thing does not necessarily diminish its essence ('Imarah, 183). It is a grave sin, it does not necessarily take away one's faith, and it does not cause him to be kafir. Because in the view of Ash'ariyyah, 'amalun (deeds) is not a requirement of faith, but as a complement to faith, the level of one's faith is not static, but dynamic according to one's deeds. The alMaturidiyyah group has similarities with the Ash'ariyyah in matters of faith and kafir. In cases of faith, the Bukhara al-Maturidiyah sect has the same ideology as the Ash'ariyyah. Both of them thought that reason could not come to terms with knowing the existence of God. Therefore, faith cannot take the form of ma'rifah or 'amal (deeds) but must be tasdīq bi al-qalb wa al-lisān. Meanwhile, alMaturidiyyah Samarkand defines faith as tashdīq bi al-qalb, not merely iqrär $b i$ al-lisān. What is spoken verbally in the form of a statement of faith will be void if the heart does not recognize verbally. However, according to him, tasdì $q$ must 
be obtained from ma'rifah. The tasdīq that is produced from ma'rifah is obtained through reason, not only through revelation.

c. The Issue of God's and Human Actions

All schools of Islamic theology agree that God has deeds. This is seen as a logical consequence of Substance having the ability to do so. The problem is a human creation. In this case, several questions are discussed in Islamic theology, namely: who created human actions, whether God or man himself or both have a role? This question then broadens to raise other questions, does God have an obligation to do something or not, and are God's actions limited to only good things or includes bad things? In answering some of the questions above, Mu'tazilah, as a rational genre, argues that God's actions are limited to only good things and do not do bad things. However, that does not mean God is incapable of doing evil deeds. God does not do bad deeds because He knows how bad they are. In the Al-Qur'an it is explained that God does not do wrong. The verses of the al-Qur'an that were used as guidelines by the Mu'tazilah, among others, Q.S. al-Anbiya'/21: 23 which means: "He was not asked about what He did, and they will be asked."

Furthermore, what became a long debate was about the efforts that humans have to do something. Questions arise from various schools of Islamic theology, whether humans have the freedom to determine God moves their actions or humans in all their activities. This question has become one of the objects of discussion among Muslim theologians. Some groups argue that humans do not have the freedom to do something, and humans are like puppets moved by a puppeteer. This opinion comes from the Jabariyyah group. Some groups argue that humans have the freedom to act, so that good and bad actions are the will of humans themselves. This opinion comes from the Qadariyyah group. In this matter, the Mu'tazilah group adheres to Qadariyyah ideology, which argues that humans can choose and freedom to do an action, even though their limitations determine human freedom. God empowers humans to do whatever they want, but God will reward them according to what they do (Nasution, 1986, 128). This view is formulated in al-'adl (God's justice), one of the al-uṣul al-khamsah (five basic teachings) Mu'tazilah. God is al-'adl (fair), according to Mu'tazilah is that God does not like damage, therefore does not interfere with human actions to do something terrible. Humans are free to do things according to their wishes with the potential given by God. His commandments are His desires, whereas His prohibitions are something He does not want. God is obliged to give His servants something good for all things, including the obligation to keep His promises, send the Messenger to deliver His message, provide sustenance, etc (al-Buti, 2008, 76). The concept of al-'adl (justice) is the keyword for Mu'tazilah to determine the obligation for God to do something. However, the 
consequences of this opinion make God seem limited in His power. That is, God's ability seems to be limited to things that are considered good and unable to do bad things (Razak and Anwar, 151).

Unlike the Mu'tazilah, the Ash'ariyah groups follow the Jabariyyah concept, which states that humans do not have freedom in their actions, but all are moved by God. The argument they use is the word of Allah in Q.S. al-Saffat verse 96, which means: "Whereas Allah created you and what you do." Based on this verse, according to Ash'ariyah, humans basically do not have the freedom to determine their actions. Human power is God's power, and human movement is determined by God's absolute will. Imam al-Ghazâlī supported this opinion of the Ash'ariyah group. The Maturidiyyah group is divided into two groups. Maturidiyyah Samarkand, who adheres to Qadariyyaah or free will, which was pioneered by al-Maturidi himself. Maturidiyyah Samarkand supports Mu'tazilah, who argues that God does not have muthlak power in determining human actions. However, the freedom that is meant here is narrower than the understanding of Mu'tazilah, because according to Maturidiyyah Samarkand, God gives power to humans so that they can distinguish between good and bad. Another one is Maturidiyyah Bukhara led by al-Bazdawi. According to alBazdawi, human actions are essentially God's actions. According to him, what is called human action is majazi in nature, not essential, meaning that God's will still overshadow the action (Razak and Anwar, 151).

\section{Conclusion}

From the above description, it can be understood that the thought process carried out by the kalam scholars has had a significant influence on the growth and development of Islamic theology. Theological schools are formed due to different thinking methods in explaining God, His oneness, His attributes, and other issues of creed. Each of the Islamic theological schools tries to strengthen their opinions with the verses of the al-Qur'an and hadiths. The arguments of the mind that have been cultivated by Greek philosophy and other civilizations have also played an important role in developing Islamic theology.

\section{References}

'Arabi, Muhyi al-Din bin, tt., Fusus Al-Hikam, tt. 'Imarah, Muhammad, 2007. Tayyarat al-fikri al-Lslami, Mesir: Dar al-Syuruq. Abduh, Muhammad, 1986. Risalah al-Tawhid, Beirut: Dar al-Ihya' al-'Ulum. Abduh, Mustafa Muhammad Yahya, tt., Afaluhu Ta'ala fi Dhau'i Tahsin al-'Aqli wa Taqbihihi Itsbatan wa Nafyan, (Kairo: Maktabah al-Iman.

Abdullah, M. Amin, 1999. Studi Agama: Normativitas atau Historisitas?, Yogyakarta: Pustaka Pelajar. 
Journal of Islamic Thought and Muslim Culture (JITMC), 2 (2), 2020|113

Abdullah, M. Amin, 200o, Falsafah Kalam, Yogyakarta: Pustaka Pelajar.

al-Buti, Muhammad Said Ramadhan, 2008. Mazahib al-Tauhid wa al-Falsafah alMu'ashirah, Damaskus: Dar al-Fikr.

Al-Gazali, 1972. al-Iqtishad fi al-I'tiqād, Mesir: Maktabah Muhammad Shobih. al-Ghazali, 13o9. al-Munqiz min al-Dlalāl, Kairo: al-Maimuniah.

al-Jabiri, Muhammad 'Abid, 1991. Bunyah al-'Aql Al-'Araby, Beirut: al-Markaz alThaqafi al-'Arabi.

al-Jabiri, Muhammad 'Abid, 2007. Madkhal ila al-Qur'an al-Adzim fi Ta'rif alQur'an, Beirut: Markaz Dirasat al-Wahdah al-Arabiyah.

al-Nasyar, Ali Syami, 1974. Manāhij al-Bahts 'inda Mufakkir al-Islām, Mesir: Dar al-Fikr al-'Arabi.

Al-Raziq, Mustafa 'Abd, 1959. Tamhid li Tārikh al-Falsafah al-Islāmiyyah, Kairo: t. al-Syamali, 'Abd, 1978. Dirasat fi Tarikh al-Falsafah al-Arabiyyah al-Islamiyyah wa Atsari Rijaliha, Beirut: Dar al-Sadr.

al-Taftazani, 'Abu al-Wafa al-Ghanimi, 1957. Dirāsāt fì al-Falsafah al-Islāmiyah, Kairo: Maktab al-Qāhirah al-Ḥadị̦sah.

Al-Taftazzani, Abu Al-Wafa al-Ganaimi, 1957. Dirāsah Fi al-Falsafah alIslāmiyyah, Kairo, Maktabah al-Qahirah al-Hadisah, 1957.

Ansari, Muhammad Fazlur Rahman, 1984. Konsepsi Masyarakat Islam Modern, Bandung: Risalah.

Arif, Syamsuddin, 2008. Orientalis dan Deabolisme Pemikiran, Jakarta: GIP.

Bakar, Oesman, 1997. Hierarki Ilmu, Bandung: Mizan.

Cook, Michael, 20oo. Commanding Right and Forbidding Wrong in Islamic Thought, Cambridge: University Press.

Dunya, Sulaiman, ed., 1968. al-Syaikh Muhammad 'Abduh bayn al-Falsafah wa Kalamiyyin, Kairo: Isa al-Bab al-Halabi.

Effendi, Djohan, 1995. "Konsep-konsep Teologis", Budhy Munawar-Rachman, ed., Kontekstualisasi Doktrin Islam dalam Sejarah, Jakarta: Paramadina.

Fakhri, Madjid, 1983. The History of Islamic Philosophy, New York: Columbia University Press.

Faris, Ahmad Ibn, 1979. Mu'jam Maqāyis al-Lughah, Dar al-Fikri.

Hanafi, Ahmad, 1979. Teologi Islam, Jakarta: Bulan Bintang.

Hanafi, Hassan, 2003. Dari Akidah ke Revolusi; Sikap Kita Terhadap Tradisi Lama, (Jakarta: Paramadina.

Ibn Khaldun, tt., Muqaddimah, Beirut: al-Bayan.

Ibn Manzur, 1978. Lisān al-'Arab, Mesir: Dar al-Misriyah li al-Ta'lif wa alTarjamah.

Jahja, Zurkani, 1996. Teologi al-Ghazali, Pendekatan Metodologi, Yogyakarta: Pustaka Pelajar.

Kartanegara, Mulyadhi, 20oo. "Membangun Kerangka Ilmu: Perspektif Filosofis", 
dalam Problem dan Prospek IAIN, Antologi Pendidikan Tinggi Islam, Komaruddin Hidayat dan Hendro Prastyo, ed., Jakarta: Dirjen Binbaga Islam, 2000.

M. Amin Nurdin, et., 2012. Sejarah Pemikiran Islam Teologi-Ilmu Kalam, Jakarta: AMZAH.

Madjid, Nurcholish, 2008. Islam Doktrin dan Peradaban, Jakarta: Paramadina.

Mudzhar, Atha', 200o. "Pendekatan Sosiologi dalam Studi Hukum Islam", Amin Abdullah et. al., ed., Mencari Islam, Studi Islam dengan Berbagai Pendekatan, Yogyakarta: Tiara Wacan.

Murata, Sachiko, 2005. The Vission of Islam, Yogyakarta: Suluh Press.

Muslih, Mohammad, 2004. Filsafat Ilmu, Kajian atas Asumsi Dasar, Paradigma dan Kerangka Teori Ilmu Pengetahuan, Yogyakarta: Belukar.

Muzani, Saiful, ed., 1995. Islam Rasional, Gagasan dan Pemikiran Prof. Dr. Harun Nasution, Bandung: Mizan.

Nasr, Sayyed Hossein, 1996. Intelektual Islam, Teologi, Filsafat, dan Gnosis, Yogyakarta: Pustaka Pelaja.

Nasution, Harun, 1986. Akal dan Wahyu dalam Islam, Jakarta: UI-Press.

Nasution, Harun, 1987. Muhammad Abduh dan Teologi Rasional Mu'tazilah, Jakarta: Universitas Indonesia Press.

Nasution, Harun, 1987. Muhammad Abduh dan Teologi Rasional Mu'tazilah, Jakarta: UI Press.

Nasution, Harun, 1986. Aliran-aliran, sejarah analisa, perbandingan, Jakarta: UI Press.

Nusabeh, Sari, 1996. "Epistemology", Oliever Leaman and Hossein Nasr, ed., History of Islam Philosophy, London: Roudladge.

Razak, Abdul and Razak, Rosihan, 2003. Ilmu Kalam, Bandung: Pustaka Setia.

Runes, Dagobert D. ed., 1977. Dictionary of Philosophy, New Jersey: Littlefield Adams \& Co.

Syafi'i, 2012. "Dari Ilmu Tauhid/Ilmu Kalam ke Teologi: Analisis Epistemologis", Jurnal Teologia, 23 (1).

Watt, Montgomery, 1992. Islamic Philosophy And Theology, Edinburgh: Edinburgh University Press.

Wirman, Eka Putra, 2013. Restorasi Teologi, Meluruskan Pemikiran Harun Nasution, Bandung: Nuansa Aulia.

Yusuf, Yunan, 199o. Corak Pemikiran Kalam Tafsir al-Azhar, Jakarta: Pustaka Panjimas.

Zahrah, Muhammad Abu, 1996. Aliran Politik dan Akidah dalam Islam, Jakarta: Logos.

Zahrah, Muhammad Abu, tt., Tārikh al-Mazāhib al-Islāmiyyah, Jilid I, t.tp.: Dar al-Fikr al-'Arabi. 